\title{
Leptin, puberty and reproductive function: lessons from animal studies and observations in humans
}

\author{
Wieland Kiess ${ }^{1}$, Werner F Blum ${ }^{1,2}$ and Michel L Aubert ${ }^{3}$ \\ ${ }^{1}$ Children's Hospital, Department of General Paediatrics and Neonatology, University of Giessen, Feulgenstr. 12, D-35385 Giessen, Germany, \\ ${ }^{2}$ Lilly Germany, Saalburgstr. 153, D-61350 Bad Homburg, Germany, and ${ }^{3}$ Division of Biology of Growth and Reproduction, Department of \\ Paediatrics, School of Medicine, University of Geneva, CH-1211 Geneva 14, Switzerland
}

(Correspondence should be addressed to W Kiess)

\section{Introduction}

The timing of sexual maturation in mammals including man is dependent on several factors: the size of the animal, life expectancy and environmental factors such as season, temperature, and perhaps most importantly, nutrition. The availability and intake of food are as crucial as environmental factors for sexual maturation, as are energy expenditure and thermogenesis (1).

Recently, the general interest in the regulation of energy expenditure, thermogenesis and weight gain has been sparked by the discovery of leptin, the $o b$ gene product $(2,3)$. Leptin is produced by adipocytes and is thought to act as an afferent satiety signal regulating appetite and weight. It is involved in the regulation of body weight through suppressing appetite and stimulating energy expenditure in rodents (4-7). The expression of the $o b$ gene and leptin serum levels are increased in various animal models of obesity and also in human obesity $(2,3,5-12)$. In human obesity a tendency towards sexual precocity has been documented $(1,13,14)$.

It has been postulated that leptin acts through specific receptors in the hypothalamus (3). Leptin production by adipose tissue is under neuroendocrine control $(15,16)$. Apart from leptin's central role in the pathophysiology and physiology of weight gain, a putative role for leptin in human and rodent pregnancy and reproduction and, perhaps most importantly, in sexual maturation has been put forward $(13,17)$.

\section{Leptin restores fertility in ob/ob mice}

Leptin is able to restore fertility in mice that are genetically deficient in leptin $(o b / o b$ mice). While both male and female $o b / o b$ mice are infertile, leptin treatment of female $o b / o b$ mice restored the oestrous cycle and leptin-treated $o b / o b$ females were able to become pregnant and deliver (18). Barash et al. (19), also treating $o b / o b$ female mice with leptin, clearly demonstrated that leptin reactivates reproductive function by a central action on the hypothalamo-pituitarygonadal axis. Similar data were obtained while treating male $o b / o b$ mice (20). These data suggested that normal leptin secretion is necessary for normal reproductive function to proceed and leptin may well be a signal triggering the onset of reproductive function.

\section{Leptin levels at the onset of puberty in normal rats}

Plasma leptin concentrations are low after weaning in the female rat and progressively increase during the prepubertal and pubertal periods (21). A leptin concentration of approximately $700 \mathrm{pg} / \mathrm{ml}$ appears to be the minimum circulating concentration which allows sexual maturation to proceed. In different models of delayed sexual maturation which had been induced by food restriction, plasma leptin levels remained very low (21). Central infusion of leptin $(10 \mu \mathrm{g} /$ day, Lilly Laboratories, Indianapolis, IN, USA) into the lateral ventricle of severely food-restricted female rats resulted in increased energy expenditure with a further loss of weight and an induction of the process of sexual maturation despite the caloric restriction (22). For example, vaginal opening occurred in 8 out of 9 rats receiving leptin, despite the presence of extreme malnutrition and very low body weight (22). It seems likely that leptin is a powerful signal for sexual maturation in the rat. The rising plasma levels of leptin in the prepubertal period in the rat might represent a permissive factor indicating that the animal is metabolically ready to go through puberty (22-24).

\section{Leptin as a metabolic gate for the onset of puberty in normal mice and rats}

Normal prepubertal female mice injected with leptin increased weight at a slower rate than controls as a result of the hormone's thinning effects, but they reproduced up to nine days earlier than controls and showed earlier maturation of the reproductive tract (25). According to Chehab et al. (25), these data suggest that leptin acts as a signal triggering puberty, thus supporting the hypothesis that fat accumulation enhances maturation of the reproductive tract. The hypothesis that leptin acts as a metabolic signal for the onset of puberty was further tested in the female rat by 
Cheung et al. (24). Leptin (6.3 $\mu \mathrm{g} / \mathrm{g}$ twice daily) was administered to normal prepubertal female rats. Their rate of sexual maturation was compared with two control groups, i.e. with rats that were pair-fed with the leptin-treated females and with rats that were fed ad libitum. Food intake in the leptin-treated group was reduced to approximately $80 \%$ of the ad libitum-fed control group, resulting in retarded weight gain in both leptin-treated and pair-fed animals. All measured indices of pubertal maturation were delayed in the pair-fed group but they were not different between the leptin-treated group and the ad libitum-fed controls (24). In a second experiment animals were food-restricted more severely to a level which was $70 \%$ of that received by animals fed ad libitum. In this experiment, leptin administration to these malnourished rats only partially restored the timing of pubertal maturation (24). The authors concluded that leptin was neither the only nor the primary signal that initiated the onset of puberty. However, leptin seemed to be a permissive factor, acting as a metabolic gate or threshold to allow sexual maturation to proceed only under adequate metabolic conditions. Other metabolic factors in addition to leptin may influence the timing of puberty onset under adverse metabolic conditions such as malnutrition, high energy expenditure or severe disease states $(13,24)$. Similar results were obtained in mice by Ahima et al. who showed that, when normal female mice were treated with leptin, pubertal development and sexual maturation were accelerated compared with control animals (26). In this study, the dose of leptin used ( $2 \mu \mathrm{g} / \mathrm{g}$ body weight/day i.p.) did not affect body weight gain.

\section{Malnutrition, energy expenditure and sexual maturation - the role of neuropeptide $\mathbf{Y}$}

Reproductive function is impaired or reduced in adverse metabolic conditions such as malnutrition, intense exercise such as that exerted by marathon runners, gymnasts and ballet dancers, and chronic diseases such as chronic infections, type- 1 diabetes, obesity and heart and kidney disease in both rodents and humans $(1,14)$. This impairment is secondary to reduced hypothalamic drive of gonadotrophin secretion. Excessive hypothalamic neuropeptide Y (NPY) release, in part accounted for by increased NPY gene expression, is present in different unfavourable metabolic conditions such as food restriction or insulin-dependent diabetes mellitus, as seen in the rat (27). The increased NPY activity might exert an inhibitory effect upon the gonadotrophin axis, thus representing a direct mechanism for inhibiting sexual maturation and reproductive function in conditions of food restriction and/or increased energy expenditure. Chronic, central infusion of NPY specifically inhibits reproductive function in the adult female (28) and male
(29) rat, but also delays sexual maturation as long as the infusion continues (30). NPY is therefore considered as a neuroendocrine mediator involved in modifying the timing of sexual maturation when nutritional conditions are suboptimal. It is clear that other neuropeptides or neuromodulators in addition to NPY could be involved in this inhibitory action.

\section{Leptin - the missing link between energy stores, NPY and the gonadotrophin- releasing hormone (GnRH)-luteinizing hormone (LH)/follicle-stimulating hormone (FSH) axis}

Since leptin affects NPY synthesis in the hypothalamus and probably NPY release, it can be hypothesized that leptin might play a role in the regulation of reproductive function and sexual maturation. Raising leptin levels under favourable nutritional conditions could then reduce NPY activity and thus suppress the postulated inhibitory effects of NPY neurons upon the GnRH-LH/ FSH axis, allowing sexual maturation and reproductive function to proceed. Similarly, a large body of evidence now supports the existence of a negative feedback system regulating food intake, leptin secretion and hypothalamic NPY expression $(3,5,22)$.

\section{Leptin levels at the onset of normal puberty in humans}

Circulating leptin levels increase during the so-called dynamic phase of juvenile obesity at the onset of puberty and related to body fatness, energy metabolism and sexual maturation (12). In boys, rising leptin serum levels precede the onset of puberty, as has been shown both in a longitudinal (31) and in two cross-sectional studies $(15,16,32,33)$. In healthy female adolescents there was a significant association between the relative total body fat and the average daytime serum leptin level, while the percentage increase in the nocturnal leptin concentration was inversely related to the percentage gain in total body weight (34). At this point of time, it is totally unclear what role circadian variations of leptin concentrations might play in the triggering of sexual maturation.

During sexual maturation, a divergent pattern of leptin levels was observed in both genders. While in girls leptin levels increased steadily with pubertal development, leptin levels in boys were highest during early puberty. Later in adolescence, testosterone levels were inversely related to leptin levels in boys, suggesting a negative feedback loop between leptin and the gonadotrophin-testosterone axis $(12,15,16,31-33)$. From these clinical studies it may again be hypothesized that leptin has a permissive role for pubertal development. However, it is unlikely that leptin per se triggers puberty in the human. 


\section{Leptin and human pregnancy}

In animal models, leptin seems to be important, not only for sexual maturation, but also for reproduction $(18,25)$. The little information that is available in respect to leptin levels during human gestation and at term is still controversial in many aspects (35-37). In addition, scarce data exist with respect to potential roles for leptin during gestation. A significant correlation exists between birth weight and leptin concentration in cord blood at birth, while no such correlation exists with maternal leptin levels $(35,37)$. An important role for leptin in foetal growth and development has therefore been hypothesized. In fact, during late human pregnancy, leptin could be one of the links between the neuroendocrine system and the adipose tissue which expands during pregnancy. A general role for leptin in reproduction seems to be likely in view of the accumulating data both in humans and in animal models.

\section{Conclusion}

It has been known for years that ballet dancers, marathon runners, and others with low body fat have disrupted reproductive systems, as do people who are starving. Women stop ovulating, and testosterone levels fall in men $(14,17)$. Because leptin is made and secreted by fat cells, the drop in leptin production that occurs in very lean or starving people might account for these changes $(38,39)$. Thus, leptin may well be one of the hormonal factors that signal to the brain when the 'body' is ready for sexual maturation. In a situation where the energetic conditions are favourable for initiating the final steps of sexual maturation, leptin might indicate the point of initiation and progression towards puberty. This hypothesis seems to be equally valid in rodents and humans. Some of the questions that still remain to be answered are: (1) just how does leptin modulate sex hormone production? (2) Is the hypothalamus at the centre of leptin's action upon the timing of puberty? (3) Which role do the NPY neurones play in leptin's effect on sexual function/maturation? (4) What factor/signal triggers the prepubertal leptin spike that is apparent in both man and rodents without any sudden weight gain? (5) What other factors are important in signalling the metabolic readiness of the body to mature sexually?

\section{References}

1 Aubert ML \& Sizonenko PC. Environmental factors and sexual maturation in rodents. Acta Paediatrica (Suppl) 1996417 86-88.

2 Zhang Y, Proenca R, Maffei M, Barone M, Leopold L \& Friedman JM. Positional cloning of the mouse obese gene and its human homologue. Nature 1994372 425-432.

3 Friedman J. Role of leptin and its receptors in the control of body weight. In Leptin - the Voice of the Adipose Tissue, pp 3-22. Eds WF Blum, W Kiess \& W Rascher. Heidelberg: J\&J Edition, JA Barth Verlag, 1997.
4 Sinha MK. Human leptin: the hormone of adipose tissue. European Journal of Endocrinology 1997136 461-464.

5 Campfield LA, Smith FJ, Guisez Y, Devos R \& Burn P. Recombinant mouse $o b$ protein: evidence for a peripheral signal linking adiposity and central neural networks. Science 1995269 546-549.

6 Halaas JL, Gajiwala KS, Maffei M, Cohen SL, Chait BT, Rabinowitz D, Lallone RL, Burley SK \& Friedman JM. Weight-reducing effects of the plasma protein encoded by the obese gene. Science 1995269 543-546.

7 Saladin R, De Vos P, Guerre-Millo M, Leturque A, Girard J, Staels B \& Auwern J. Transient increase in obese gene expression after food intake or insulin administration. Nature 1995377 527-529.

8 Maffei M, Halaas J, Ravussin E, Pratley RE, Lee GH, Zhang Y, Fei H, Kim S, Lallone R, Ranganathan S, Kern PA \& Friedman JM. Leptin levels in human and rodent: measurement of plasma leptin and ob RNA in obese and weight-reduced subjects. Nature Medicine 19951 1155-1161.

9 Lönqvist F, Amer P, Nordfors L \& Schalling M. Overexpression of the obese (ob) gene in adipose tissue of human obese subjects. Nature Medicine 19951 950-953.

10 Considine RV, Sinha MK. Heiman ML, Kriauciunas A, Stephens TW, Nyce MR, Ohannesian JP, Marco CC, Mckee U, Bauer TL \& Caro JF. Serum immunoreactive-leptin concentrations in normal-weight and obese humans. New England Journal of Medicine 1996334 292-295.

11 Havel PJ, Kasim-Karakas S, Mueller W, Johnson PR, Gingerich RL \& Stern JS. Relationship of plasma leptin to plasma insulin and adiposity in normal weight and overweight women: effects of dietary fat content and sustained weight loss. Journal of Clinical Endocrinology and Metabolism 199681 4406-4413.

12 Lahlou N, Landais P, De-Boissieu D \& Bougneres PF. Circulating leptin in normal children and during the dynamic phase of juvenile obesity: relation to body fatness, energy metabolism, caloric intake, and sexual dimorphism. Diabetes $199746989-$ 993.

13 Steiner RA. Editorial: lords and ladies leapin' on leptin. Endocrinology 1996137 4533-4534.

14 Frisch RE. Pubertal adipose tissue: is it necessary for normal sexual maturation? Federation Proceedings 198039 2395-2400.

15 Blum WF, Englaro P, Heiman M, Attanasio AM, Kiess W \& Rascher W. Plasma leptin levels in healthy children and adolescents: dependence on body mass index, body fat mass, gender, pubertal stage and testosterone. Journal of Clinical Endocrinology and Metabolism 199782 2904-2910.

16 Blum WF, Englaro P, Heiman M, Attanasio AM, Kiess W \& Rascher W. Clinical studies of serum leptin. In Leptin - the Voice of the Adipose Tissue. Eds WF Blum, W Kiess \& W Rascher. Heidelberg: J\&J Edition, JA Barth Verlag, 1997.

17 Vogel G. Leptin: a trigger for puberty? Science $19962741466-$ 1467.

18 Chehab F, Lim M \& Lu R. Correction of the sterility defect in homozygous obese female mice by treatment with the human recombinant leptin. Nature Genetics 199612 318-320.

19 Barash IA, Cheung CC, Wigle DS, Ren H, Kabitting EB, Kuijer JL, Clifton DK \& Steiner RA. Leptin is a metabolic signal to the reproductive system. Endocrinology 1996133 3144-3147.

20 Mounzih K, Lu R \& Chehab FF. Leptin treatment rescues the sterility of genetically obese ob/ob males. Endocrinology 1997138 1190-1193.

21 Aubert ML, Gruaz-Gumowski NM, Heritier A, Pierroz DD, Lalaoui M, Vuagnat B, Aebi A, Pralong FP, Englaro P, Blum WF \& Sizonenko PC. Leptin could represent a metabolic signal for sexual function and GH secretion: studies during sexual maturation and in adverse metabolic conditions. In Leptin - the Voice of the Adipose Tissue. Eds WF Blum, W Kiess \& W Rascher. Heidelberg: J\&J Edition, JA Barth Verlag, 1997.

22 Gruaz-Gumowski NM, Lalaoui M, Englaro P, Sizonenko PC, Blum WF \& Aubert ML. Chronic administration of leptin into the lateral ventricle can induce sexual maturation in severely food-restricted female rats. Endocrinology 1997 (In Press). 
23 Zachow RJ \& Magoffin DA. Direct intraovarian effects of leptin: impairment of the synergistic action of IGF-I on FSH-dependent estradiol-17 $\beta$ production by rat ovarian granulosa cells. Endocrinology 1997138 847-850.

24 Cheung CC, Thornton JE, Kuijper JL, Weigle DS, Clifton DK \& Steiner RA. Leptin is a metabolic gate for the onset of puberty in the female rat. Endocrinology 1997138 855-858.

25 Chehab F, Mounzih K, Lu R \& Lim ME. Early onset of reproductive function in normal mice treated with leptin. Science 1996275 88-90.

26 Ahima RS, Dushay J, Flier SN, Prabakaran D \& Flier JS. Leptin accelerates the onset of puberty in normal female mice. Journal of Clinical Investigation 199799 391-395.

27 Gruaz NM, Pierroz DD, Rohner-Jeanrenaud F, Sizonenko PC \& Aubert ML. Evidence that NPY could represent a neuroendocrine inhibitor of sexual maturation in unfavourable metabolic conditions in the rat. Endocrinology 1993133 1891-1895.

28 Catzeflis C, Pierroz DD, Rohner-Jeanrenaud F, Rivier J, Sizonenko PC \& Aubert ML. Neuropeptide Y administered chronically into the lateral ventricle profoundly inhibits both the gonadotropic and the somatotropic axis in intact adult female rats. Endocrinology 1993 $132224-234$.

29 Pierroz DD, Catzeflis C, Aebi AC, Rivier JE \& Aubert ML. Chronic administration of NPY into the lateral ventricle inhibits both the pituitary-testicular axis and GH and IGF-I secretion in intact adult male rats. Endocrinology 1996137 3-12.

30 Pierroz DD, Gruaz NM, d'Alleves V \& Aubert ML. Chronic administration of neuropeptide $\mathrm{Y}$ into the lateral ventricle starting at 30 days of life delays sexual maturation in the female rat. Neuroendocrinology 199561 293-300.

31 Mantzoros CS, Flier JS \& Rogol AD. A longitudinal assessment of hormonal and physical alterations during normal puberty in boys. V. Rising leptin levels may signal the onset of puberty. Journal of Clinical Endocrinology and Metabolism 199782 10661070.

32 Clayton $\mathrm{P} \&$ \& Gill MS. Serum leptin, body mass index and body composition: studies in children, adults and the elderly. In
Leptin - the Voice of the Adipose Tissue, pp 219-227. Eds WF Blum, W Kiess \& W Rascher. Heidelberg: J\&J Edition, JA Barth Verlag, 1997.

33 Clayton PE, Gill MS, Hall CM, Tillmann V, Whatmore AJ \& Price DA. Serum leptin through childhood and adolescence. Clinical Endocrinology 199746 727-733.

34 Matkovic V. Gain in body fat is inversely related to the nocturnal rise in serum leptin level in young females. Journal of Clinical Endocrinology and Metabolism 199782 1368-1372.

35 Kiess W, Schubring C, Prohaska F, Englaro P, Rascher W, Attanasio A \& Blum WF. Leptin in amniotic fluid at term and at mid gestation. In Leptin - the Voice of the Adipose Tissue, pp 192197. Eds WF Blum, W Kiess \& W Rascher. Heidelberg: J\&J Edition, JA Barth Verlag, 1997.

36 Butte NF, Hopkinson JM \& Nicolson MA. Leptin in human reproduction: serum leptin levels in pregnant and lactating women. Journal of Clinical Endocrinology and Metabolism 199782 585-589.

37 Schubring C, Kiess W, Englaro P, Rascher W, Dötsch J, Hanitsch S, Attanasio A \& Blum WF. Levels of leptin in maternal serum, amniotic fluid, and arterial and venous cord blood: relation to neonatal and placental weight. Journal of Clinical Endocrinology and Metabolism 199782 1480-1483.

38 Köpp W, Blum WF, von Prittwitz S, Ziegler A, Lübbert H, Emons G, Herzog W, Herpertz S, Deter HC, Remschmidt H \& Hebebrand J. Low leptin levels predict amenorrhea in underweight and eating disordered females. Molecular Psychiatry 19972 335-401.

39 Hebebrand J, Blum WF, Barth N, Coners H, Englaro P, JuuI A, Ziegler A, Warnke A, Rascher W, Remschmidt H. Leptin levels in patients with anorexia nervosa are reduced in the acute stage and elevated upon short-term weight restoration. Molecular Psychiatry $19972330-334$.

Received 25 September 1997

Accepted 14 October 1997 